\title{
Micellar Counterion Binding for Alkylpyridinium Iodides Probed by N-Sulfopropylacridinium Fluorescence Quenching
}

\author{
Tsuyoshi Asakawa* ${ }^{*}$ Keisuke Iriyama, Akio OHTA and Shigeyoshi Miyagishi \\ Department of Chemistry and Chemical Engineering, Faculty of Engineering, Kanazawa University \\ (Kanazawa 920-8667, JAPAN)
}

Edited by T. Kato, Tokyo Metr. Univ., and accepted April 12, 2004 (received for review January 29, 2004)

\begin{abstract}
Fluorescence quenching using N-sulfopropylacridinium (SPA) makes it possible to determine the degree of micellar counterion binding $(\beta)$ of alkylpyridinium iodide in aqueous solution. But with quinoline derivatives as a halide-sensitive fluorescence probe, this was not possible. Fluorescence was quenched by iodide ions as indicated by linear Stern-Volmer plots, the slope of which was noted to decrease beyond cmc owing to micellar counterion binding with SPA excitation at $416 \mathrm{~nm}$. The slope was found to significantly increase beyond cmc with SPA excitation at $357 \mathrm{~nm}$. The abrupt quenching was due to absorption bands resulting from chargetransfer interactions of pyridinium and iodide ions. SPA fluorescence was quenched by iodide and bromide ions but virtually unaffected by nitrate or sulfate ions. Selective counterion binding of iodide ions is thus shown to be detectable.
\end{abstract}

Key words: the degree of micellar counterion binding, fluorescence quenching, Nsulfopropylacridinium, alkylpyridinium iodide, cmc of surfactant mixture

\section{1 緒言}

イオン性界面活性剤の水溶液物性は, 疎水基の長さ や種類だけでなく対イオンの種類によっても大きく変 化する (1)。これは対イオンの種類によって, ミセル 会合体表面への結合度が異なるためであり，対イオン 結合度はミセルの大きさや形状を支配する。従って， 各種対イオンのミセルへの対イオン結合度は, 水溶液 物性の評価に重要な因子の一つとなる。これまで対イ オン結合度は，起電力法，電気伝導度法打よび NMR 法等により決定されてきた $(1-5)$ 。広く用いられてい るイオン選択性電極の起電力法では, 共存イオンの影 響や界面活性剤の電極への吸着などによるデータの再 現性が問題となることもあり，また，各種イオンに対 応した電極を用意する必要がある。電気伝導度法では, 界面活性剂濃度依存性から対イオン解離度の指標が評 価されているが，共存イオン濃度が高いときや各種イ
オンが共存するとき，対イオン結合度の評価は困難で ある。

ヨウ化物イオンを対イオンとするカチオン界面活性 剂は, 一般にクラフト点が高く, 臨界ミセル濃度 (CMC) が低い。これは，ヨウ化物イオンの水和半径が 小さいためミセル表面のカチオン親水基に近づきやす いこと，アンモニウムと共有結合性を呈するため沈殿 を生成しやすいことに対応している。ヨウ化ドデシル ピリジニウム（DPI）水溶液の起電力測定によると, CMC $5.7 \mathrm{mM}$ 打よび対イオン結合度 0.756 が報告され ているが，ヨウ化物イオンを対イオンとするカチオン 界面活性剂の基本的物性の報告例は少ない（3）。

本研究は, アクリジン誘導体の蛍光に対するハロゲ ン化物イオンの高感度な消光とそのイオン選択性を利 用し, 対イオン結合度の簡便な評価法を確立して, 界 面活性剤混合系扎よび対イオン混合系におけるミセル 表面への対イオンの競争的結合に関する知見を得るこ

\footnotetext{
* Correspondence to: Tsuyoshi Asakawa, Department of Chemistry and Chemical Engineering, Faculty of Engineering, Kanazawa University, 2-40-20 Kodatsuno,Kanazawa 920-8667, JAPAN

E-mail: asakawa@t.kanazawa-u.ac.jp
} 
とを目的とする。ドデシルピリジニウム塩は，ヨウ化 物イオンと電荷移動相互作用をすることが知られてお り $(6,7)$, この吸収バンドの蛍光消光挙動に対する影響 を検討した。また，フルオロカーボン鎖を有するピリ ジニウム塩を合成し, その水溶液物性と炭化水素系界 面活性剂との混合系について検討した。本研究では, 蛍光強度測定という比較的簡便な方法で $\mathrm{CMC}$ を決定 し，カチオン性ミセル系に打ける対イオンの結合状態 に関する知見を得た。

\section{2 実験}

\section{$2 \cdot 1$ 試料}

N-sulfopropylacridinium(SPA) は, Molecular Probe 社より購入したものをそのまま使用した。ピリジニウ 厶塩型界面活性剂は, 対応するハロゲン化アルカンを ピリジンとアセトニトリル中で 2 時間還流して得た。 エーテル洗浄後, アセトンで 3 回再結晶して精製した （8）。また，アルキルトリメチルアンモニウム塩は，東 京化成工業株式会社から購入したものをアセトンとエ タノール混合溶媒で 3 回再結晶した。

\section{$2 \cdot 2$ 蛍光測定}

二次蒸留水を用いて, $7 \times 10^{-7} \mathrm{M} \mathrm{SPA}$ 水溶液を調整 後, この水溶液でカチオン界面活性剤や無機塩を溶解 させた。日立 F- 2000 型分光蛍光光度計を用い, $25^{\circ} \mathrm{C}$ の 恒温下に抢いて蛍光スペクトルを測定した。界面活性 剂や無機塩の添加による蛍光スペクトルのシフトは観 測されず，蛍光波長ピークに打ける蛍光強度を記録し た。

\section{3 結果および考察}

$3 \cdot 1$ 蛍光スペクトルに対する各種イオンの影響

N-Sulfopropylacridinium （SPA）の蛍光消光挙動に関す る基礎的な知見を得るため, 水溶液中打よびその添加 塩系について検討した。 $7 \times 10^{-7} \mathrm{M} \mathrm{SPA}$ 水溶液の励起打 よび蛍光スペクトルを Fig. 1 に示した。357 nm の吸収 極大で励起すると, $485 \mathrm{~nm}$ を発光ピークとする強い蛍 光が観察されるのに対し，416 $\mathrm{nm}$ で励起すると蛍光強 度が小さくなるが, $485 \mathrm{~nm}$ を発光ピークとするスペク トルに変化は見られなかった。また，いずれの励起波 長でも $\mathrm{NaI}$ や $\mathrm{NaBr}$ などの消光剂濃度の増加と共に蛍 光強度が減少し, 蛍光波長のシフトは見られなかった。 な打, 界面活性凨水溶液系で，ミセル形成によっても 蛍光波長シフトは観察されないことを確認した。

SPAの蛍光はハロゲン化物イオンとの分子衝突によ り消光され, 次の Stern-Volmer 式に従うことが知られ

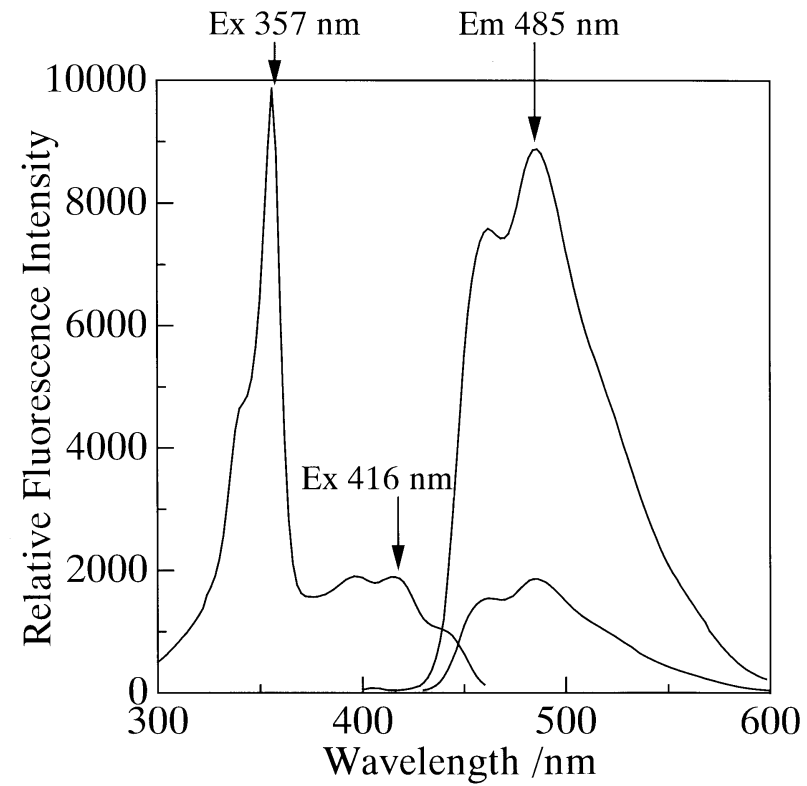

Fig. 1 Excitation and Emission Spectra of SPA in Aqueous Solutions.

ている (9)。

$$
\mathrm{I}_{0} / \mathrm{I}=1+\mathrm{K}_{\mathrm{SV}}[\mathrm{Q}]
$$

従って, SPAの蛍光強度 $\mathrm{I}_{0}$ と消光剂存在下における蛍 光強度 I との比を消光剤濃度 $[\mathrm{Q}]$ に対してプロットする と, 直線の傾きから Stern-Volmer 定数 $\mathrm{K}_{\mathrm{SV}}$ が得られる。 各種無機塩類による蛍光消光を Stern-Volmer プロット した結果を Fig. 2 に示した。いずれの系も良い直線関 係が成立するが, 直線の傾きに大きな相違が現れた。 $\mathrm{NaI}$ と $\mathrm{NaBr}$ の $\mathrm{K}_{\mathrm{SV}}$ はそれぞれ 452, $345 \mathrm{M}^{-1}$ であるのに 対し, $\mathrm{NaCl}$ の $\mathrm{K}_{\mathrm{SV}}$ は $11.6 \mathrm{M}^{-1}$ とかなり小さくなってい る。また, $\mathrm{NaNO}_{3}$ と $\mathrm{Na}_{2} \mathrm{SO}_{4}$ の $\mathrm{K}_{\mathrm{SV}}$ はそれ艺れ 1.9, 0.9 $\mathrm{M}^{-1}$ で，ほとんど消光しないといえる。なお，対応する カリウム塩やリチウム塩を用いても同様な結果を確認 している。このような SPAの蛍光消光のイオン選択性 を利用すれば，ミセル系でアニオンの競争結合に関す る知見が期待される。特に, SPA 蛍光に対する塩化物 イオンによる消光感度が低く, N-ethoxycarbonylmethyl-6-methoxyquinolinium bromide(MQAE) などの キノリン誘導体蛍光プローブと相違点があることがわ かった（10）。

\section{$3 \cdot 2$ SPA 蛍光消光に対する励起波長の影響}

次に, ヨウ化物イオンを対イオンとするピリジニウ 么塩型界面活性剂水溶液系に打ける SPA 蛍光消光挙動 を検討した。Fig. 3 は $\mathrm{C}_{6} \mathrm{~F}_{13} \mathrm{CH}_{2} \mathrm{CH}_{2} \mathrm{NC}_{5} \mathrm{H}_{5} \mathrm{I}$ (HFOPI) 抒 よび $\mathrm{C}_{12} \mathrm{H}_{25} \mathrm{NC}_{5} \mathrm{H}_{5} \mathrm{I}$ (DPI) 水溶液の Stern-Volmer プロッ 卜を示すが，416 nm で励起した場合は CMCで傾きが 


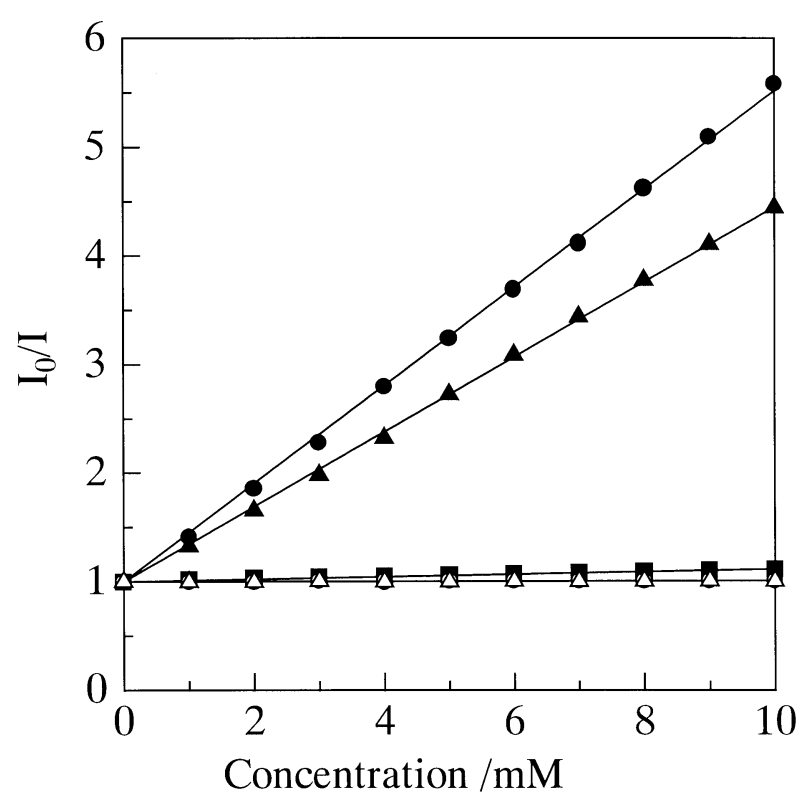

Fig. 2 Stern-Volmer Plots for Quenching of SPA Fluorescence by Various Ions.

(○) $\mathrm{NaI},(\boldsymbol{\Delta}) \mathrm{NaBr},(\boldsymbol{\square}) \mathrm{NaCl},(\bigcirc) \mathrm{NaNO}_{3},(\triangle)$ $\mathrm{Na}_{2} \mathrm{SO}_{4}$.

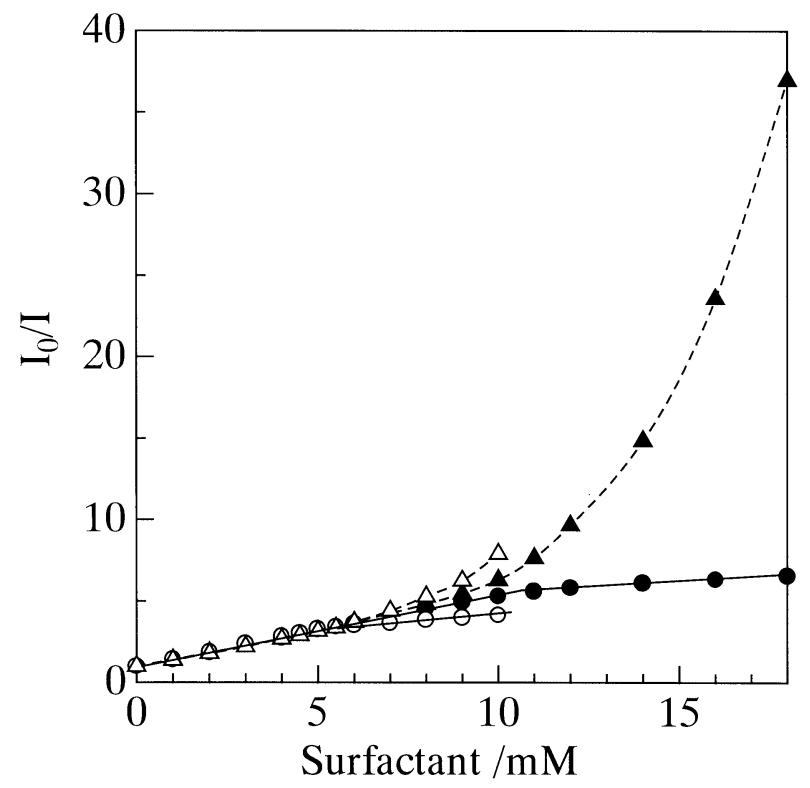

Fig. 3 Effect of Excitation Wavelength on Fluorescence Quenching.

Ex 416 nm (○) HFOPI, (○) DPI,

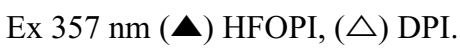

小さくなるのに対し， $357 \mathrm{~nm}$ で励起した場合は $\mathrm{CMC}$ 以上で傾きがかなり大きくなった。この顕著な消光は, ミセル形成に伴いピリジニウム塩とヨウ化物イオンと の電荷移動相互作用によりイオン対が生成し，300 から $400 \mathrm{~nm}$ 付近までの幅広い吸収帯が新たに出現するため と考えられる $(6,7)$ 。また, CMC 以下での消光挙動は, 励起波長に依存しないことからも，励起波長 $357 \mathrm{~nm}$ で の $\mathrm{CMC}$ 以上に打ける顕著な見かけの消光は, 励起光が イオン対の吸収バンドに吸収されるためであると考え られる。一方，励起波長 $416 \mathrm{~nm}$ のときは，このような 吸収バンドの影響がなく, CMC 以上で Stern-Volmer プ ロットの傾きが小さくなった。これは，既に報告した キノリン誘導体蛍光消光挙動と同様に, ミセル表面へ のヨウ化物イオンの結合によりバルク水相中のフリー なヨウ化物イオン濃度が減少するためである（10）。 従って, 観測される蛍光強度比からフリーなヨウ化物 イオン濃度を見積もり，ミセルに対するヨウ化物イオ ンの対イオン結合度 $\beta$ が決定できる。また, SternVolmer プロットに打ける屈曲点から CMC も決定でき, その結果を Table 1 にまとめた。 HFOPI と DPI の $\mathrm{K}_{\mathrm{SV}}$ は， $\mathrm{NaI} の 452 \mathrm{M}^{-1}$ にほぼ対応するが，4\%程度小さい のはカチオン界面活性剂が完全解離でないこと, ある

Table 1 Stern-Volmer Constant of Surfactant Monomer, $\mathrm{CMC}$ and the Degree of Counterion Binding by Fluorescence Quenching Method at $25^{\circ} \mathrm{C}$.

\begin{tabular}{|c|c|c|c|c|c|c|}
\hline \multirow{2}{*}{ Surfactant } & \multicolumn{2}{|c|}{$\mathrm{K}_{\mathrm{SV}} / \mathrm{M}^{-1}$} & \multicolumn{2}{|c|}{$\mathrm{CMC} / \mathrm{mM}$} & \multicolumn{2}{|c|}{$\beta$} \\
\hline & SPA & MQAE & SPA & MQAE & SPA & MQAE \\
\hline $\begin{array}{c}\mathrm{C}_{6} \mathrm{H}_{13} \mathrm{CH}_{2} \mathrm{CH}_{2} \mathrm{NC}_{5} \mathrm{H}_{5} \mathrm{I} \\
\text { (HFOPI) }\end{array}$ & 435 & - & 10.7 & - & 0.70 & - \\
\hline $\begin{array}{c}\mathrm{C}_{12} \mathrm{H}_{25} \mathrm{NC}_{5} \mathrm{H}_{5} \mathrm{I} \\
\text { (DPI) }\end{array}$ & 432 & - & 5.3 & - & 0.77 & - \\
\hline $\begin{array}{c}\mathrm{C}_{12} \mathrm{H}_{25} \mathrm{NC}_{5} \mathrm{H}_{5} \mathrm{Br} \\
\text { (DPB) }\end{array}$ & 373 & 380 & 12.3 & 12.1 & 0.73 & 0.72 \\
\hline $\begin{array}{c}\mathrm{C}_{12} \mathrm{H}_{25} \mathrm{~N}\left(\mathrm{CH}_{3}\right)_{3} \mathrm{Br} \\
\text { (DTAB) }\end{array}$ & 356 & 362 & 15.9 & 15.4 & 0.73 & 0.72 \\
\hline $\begin{array}{c}\mathrm{C}_{14} \mathrm{H}_{29} \mathrm{~N}\left(\mathrm{CH}_{3}\right)_{3} \mathrm{Br} \\
\text { (TTAB) }\end{array}$ & 371 & 369 & 3.9 & 3.8 & 0.79 & 0.78 \\
\hline $\begin{array}{c}\mathrm{C}_{16} \mathrm{H}_{33} \mathrm{~N}\left(\mathrm{CH}_{3}\right)_{3} \mathrm{Br} \\
(\mathrm{CTAB})\end{array}$ & 382 & 373 & 1.0 & 1.0 & 0.80 & 0.89 \\
\hline $\begin{array}{c}\mathrm{C}_{12} \mathrm{H}_{25} \mathrm{NC}_{5} \mathrm{H}_{5} \mathrm{Cl} \\
\text { (DPC) }\end{array}$ & 12.9 & 233 & - & 16.1 & - & 0.74 \\
\hline $\begin{array}{c}\mathrm{C}_{12} \mathrm{H}_{25} \mathrm{~N}\left(\mathrm{CH}_{3}\right)_{3} \mathrm{Cl} \\
\text { (DTAC) }\end{array}$ & 15.1 & 211 & - & 24.4 & - & 0.53 \\
\hline
\end{tabular}


いはカチオン界面活性剂モノマーの存在が両性イオン であるSPA とヨウ化物イオンとの分子衝突を阻害して いることを示唆する。また, SPA は MQAE と同程度の 消光感度をもつこと, 長波長側に吸収帯を有する SPA はヨウ化アルキルピリジニウム塩系の CMC P $\beta$ が決 定できることがわかった。SPA 蛍光消光法によるDPI の $\mathrm{CMC}$ や $\beta$ は, 水溶液の起電力測定による文献值で ある CMC $5.7 \mathrm{mM}$ 打よび $\beta 0.756$ と良い一致を示し (3)，この方法が対イオン結合度の評価に有効であるこ とが確認できた。しかし, MQAE 蛍光プローブは, ヨ ウ化物イオンとピリジン環との電荷移動相互作用によ る吸収バンドのため，アルキルピリジニウム塩系の対 イオン結合度の評価には適用できなかった。一方，臭 化物イオンを対イオンとする界面活性剤では, SPA と MQAE による CMC や $\beta$ は良い一致を示した。また， 塩化物イオンを対イオンとする界面活性剤では, SPA により $\mathrm{CMC} や \beta$ を決定することはできなかった。

\section{$3 \cdot 3$ 添加塩系における SPA 蛍光消光挙動}

励起波長 $357 \mathrm{~nm}$ における顕著な見かけの消光が，ピ リジン環とヨウ化物イオンとのイオン対生成によるこ とをさらに確認するため, 各種添加塩系に打ける SPA 蛍光消光の DPI 濃度依存性について検討した。一定濃

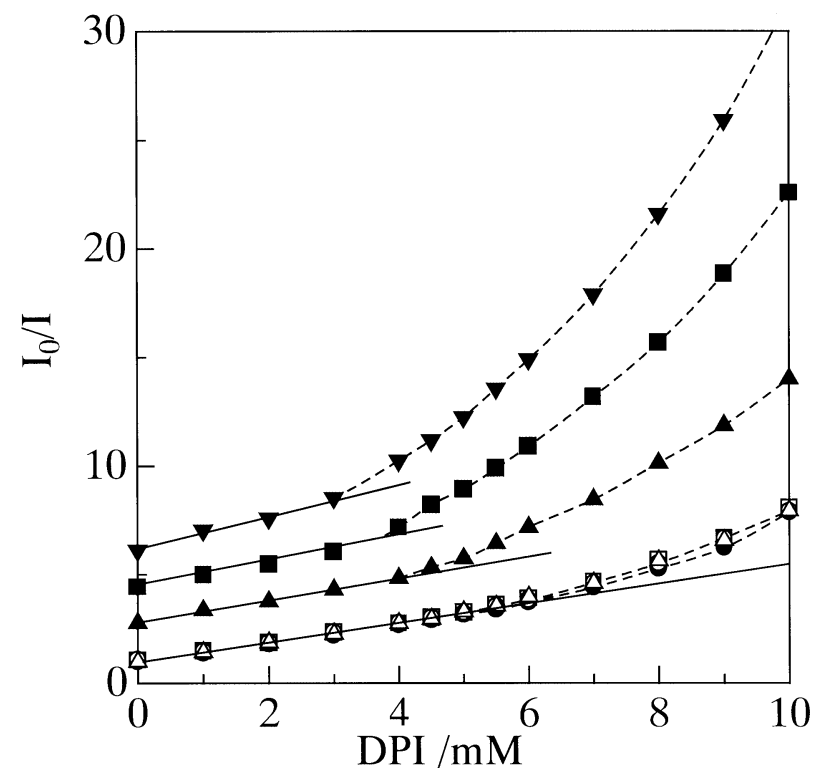

Fig. 4 Apparent Quenching Behavior on DPI Micelle Formation with SPA Excitation at $357 \mathrm{~nm}$.

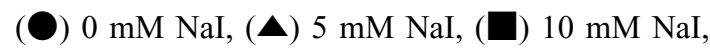

(จ) $15 \mathrm{mM} \mathrm{NaI}$,

(○) $10 \mathrm{mM} \mathrm{NaCl},(\triangle) 10 \mathrm{mM} \mathrm{NaNO}_{3},(\square) 10 \mathrm{mM}$ $\mathrm{Na}_{2} \mathrm{SO}_{4}$.
度の $\mathrm{NaI}, \mathrm{NaCl}, \mathrm{NaNO}_{3}, \mathrm{Na}_{2} \mathrm{SO}_{4}$ 添加塩存在下における SPA 蛍光消光について, DPI 濃度に対して SternVolmer プロットした結果を Fig. 4 に示した。なお， 10 $\mathrm{mM} \mathrm{NaCl}, \mathrm{NaNO}_{3}, \mathrm{Na}_{2} \mathrm{SO}_{4}$ 添加系のプロットは重なって いる。 $\mathrm{NaI}$ 濃度増加とともに良く消光が起こるが, $\mathrm{NaCl}, \mathrm{NaNO}_{3}$ および $\mathrm{Na}_{2} \mathrm{SO}_{4}$ 添加塩による影響は少ない ことがわかった。また, 顕著な消光が起こり始める濃 度は $\mathrm{CMC}$ に対応し, $\mathrm{NaI}$ 濃度増加に伴い $\mathrm{CMC}$ が低下 していることがわかる。CMC 以下では, Stern-Volmer プロットに打いて良い直線関係が成立するが，CMC 以 上で顕著な消光が起こり, NaI 濃度増加とともに影響が 大きくなった。CMC 以下では，ヨウ化物イオンによる 消光により Stern-Volmer プロットに従うのに対し， $\mathrm{CMC}$ 以上では, 電荷移動相互作用による吸収帯の出現 により顕著な見かけの消光が起こると考えられる。ま た，ピリジン環とのヨウ化物イオン対生成に対する塩 化物イオン, 硝酸イオンや硫酸イオンによる影響は少 ないと言える。

以上の結果より，ヨウ化物イオンのミセルへの結合 度を評価するには, 電荷移動相互作用による吸収帯の 影響のない $416 \mathrm{~nm}$ で励起して SPA 蛍光消光挙動を調 べる必要があることがわかった。Fig. 5 は，DPI の NaI 添加塩系に打ける Stern-Volmer プロットを示した。

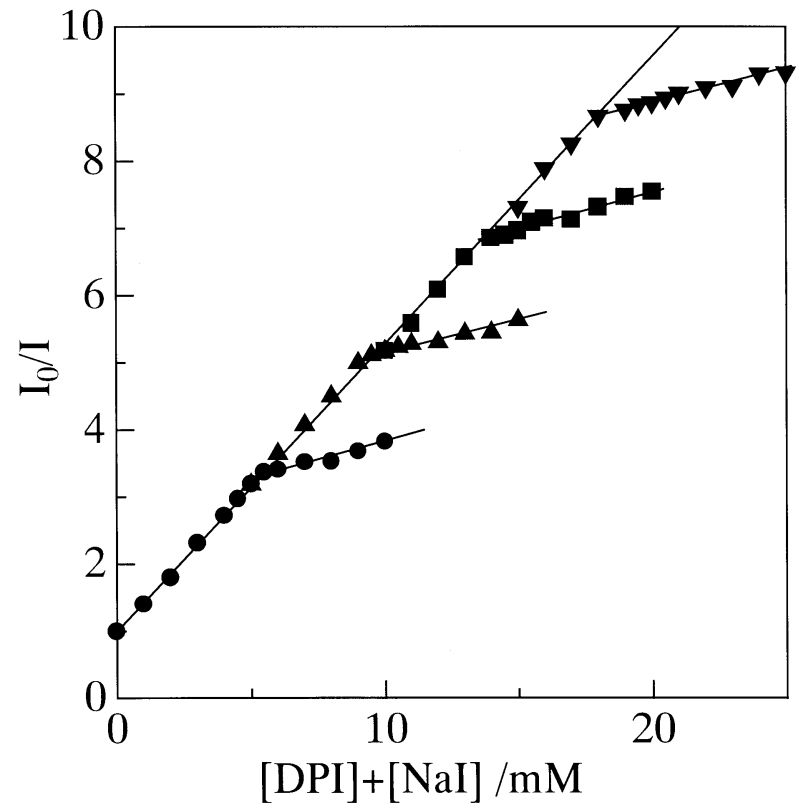

Fig. 5 Effect of Iodide Concentration on Fluorescence Quenching in DPI Systems with SPA Excitation at $416 \mathrm{~nm}$.

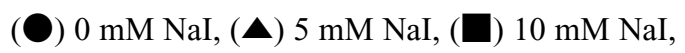
(จ) $15 \mathrm{mM} \mathrm{NaI}$. 
$\mathrm{CMC}$ 以下では，良い直線関係が成立し，K $\mathrm{K}_{\mathrm{SV}}$ はほぼ一 定であった。CMCに打いて明確な屈曲点が現れ，NaI 濃度 $5,10,15 \mathrm{mM}$ と増加とともに $\mathrm{CMC}$ が 4.3, 3.6, 2.9 $\mathrm{mM}$ と低下した。また， CMC 以上における SternVolmer プロットの傾きは, NaI 濃度に依存せず, 対イ オン結合度は $0.78 \pm 0.02$ でほぼ一定となった。測定し た濃度範囲では，添加塩濃度による対イオン結合度へ の影響は少ないと評価できる。なお， $15 \mathrm{mM} \mathrm{NaI}$ 以上 の濃度では， $25^{\circ} \mathrm{C} に$ 打いて沈殿を生じた。

\section{$3 \cdot 4$ 混合系における SPA 蛍光消光挙動}

次に, フルオロカーボン鎖を有する HFOPI とその混 合系について検討した。Fig. 6 は, HFOPI-DPI 混合系 打よび単独系に打ける蛍光消光挙動を示した。塩化物 イオンを対イオンとする DPCでは，ほとんど消光が起 こらないのに対し，ヨウ化物イオンを対イオンとする HFOPI および DPI では, 良く消光が起こっている。 CMC 以下での Stern-Volmer プロットの傾きが, HFOPI と DPI で相違がなく，ヨウ化物イオンにより選 択的に消光が起こり，フルオロカーボン鎖の影響がな いことを示している。一方, $\mathrm{CF}_{2}$ 基の疎水性が $\mathrm{CH}_{2}$ 基 の 1.5 倍程度であることから, $\mathrm{CF}_{2}$ 基 6 個と $\mathrm{CH}_{2}$ 基 2 個 有する HFOPI は， $\mathrm{CH}_{2}$ 基 11 個もつ界面活性剂に相当 する。従って, HFOPI の CMC が DPI よりも高くなる

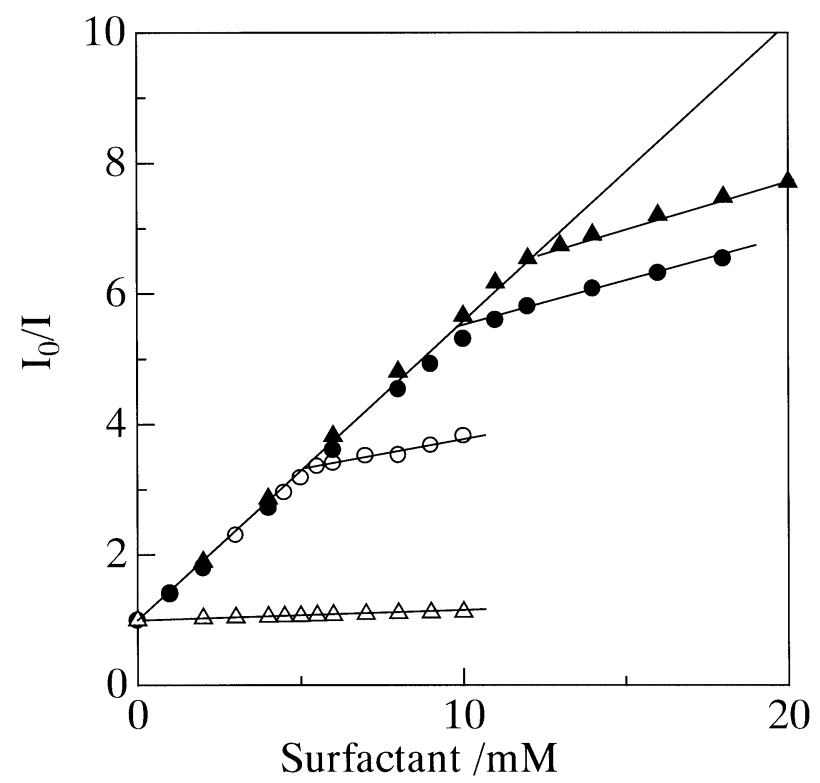

Fig. 6 Stern-Volmer Plots for Fluorescence Quenching by Pyridinium Surfactants with SPA Excitation at 416 $\mathrm{nm} . \mathrm{X}_{\mathrm{F}}$ is the mole fractions of HFOPI in mixtures. (๑) HFOPI, $(\bigcirc)$ DPI, $(\triangle)$ DPC, $(\Delta) \mathrm{X}_{\mathrm{F}} 0.8$ HFOPI-DPI.
のは妥当と評価できる。また，HFOPI の $\beta 0.70$ は DPI の $\beta 0.77$ より小さいことがわかった。これはHFOPI の 方が踈水基の長さが短いため, 小さな球状ミセルを形 成するためと予想される。一方, HFOPI-DPI 混合系に 打ける HFOPI の仕込みモル分率を $\mathrm{X}_{\mathrm{F}}$ とすると, $\mathrm{X}_{\mathrm{F}} 0.8$ では, Stern-Volmer プロットにおける屈曲点がそれぞ れ単独系よりも高濃度側に存在する。屈曲点すなわち 混合 $\mathrm{CMC}$ が単独系より高くなる現象は，ミセル中で両 界面活性剤が混合しにくいことを示している（11）。そ こで, 混合 CMC の組成依存性を調べ，ミセル中の両界 面活性剂の混和性を評価した。

ミセル中での界面活性剂 2 成分間の相互作用の評価 には, 水中に形成されたミセルを擬似相分離とみなし て正則溶液論を適用する方法が良く利用されており， 混合 CMC は次式で与えられる (12)。

$$
\begin{aligned}
\mathrm{CMC}^{1+\beta \mathrm{m}}= & \mathrm{CMC}_{1}{ }^{1+\beta 1} \mathrm{x}_{1} \exp \left[\omega \mathrm{x}_{2}{ }^{2}\right] \\
& +\mathrm{CMC}_{2}^{1+\beta 2} \mathrm{x}_{2} \exp \left[\omega \mathrm{x}_{1}{ }^{2}\right]
\end{aligned}
$$

ここで， $\mathrm{x}$ はミセル組成， $\omega$ は相互作用パラメーター， 添え字 1, 2 は界面活性剂成分をそれぞれ示す。なお， 混合ミセルの対イオン結合度 $\beta_{\mathrm{m}}$ は, 混合ミセル組成に 対して加成性を仮定し, SPA 蛍光消光法により求めた $\beta$ から計算した。混合 $\mathrm{CMC}$ の計算結果を, SPA 蛍光消 光法により決定した実測值とともに Fig. 7 に示した。

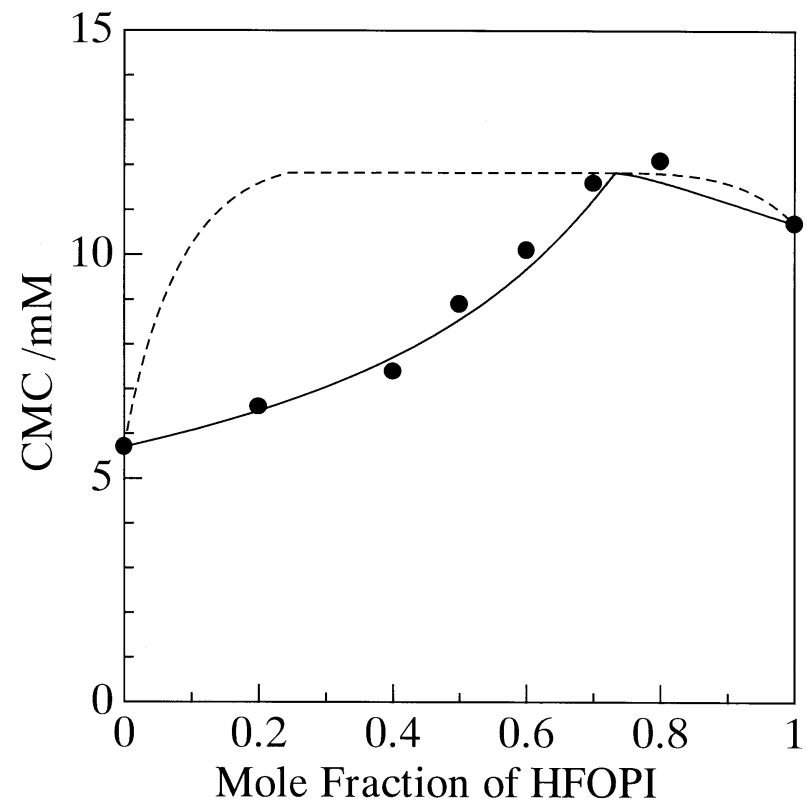

Fig. 7 CMC for HFOPI-DPI Mixtures. The plotted points are experimental values.

The solid and dashed lines are the CMC and micellar composition curves predicted by the regular solution theory using interaction parameter $\omega=2.2$, respectively. 
正則溶液論による相互作用パラメーター $\omega=2.2$ の計算 $\mathrm{CMC}$ 曲線は山型を示し， 2 種類のミセルの共存を示唆 する (12)。すなわち, モル分率 0.25 と 0.75 の間でミ

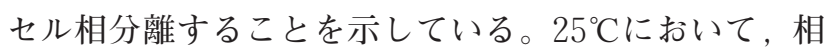
分離に必要な疎水基 $\mathrm{CF}_{2}$ 基の炭素数は 8 個以上である と報告されており，HFOPI-DPI 混合系はその条件を満 たしてはいないが，ミセル相分離が示唆される。これ はヨウ化物イオンのミセルに対する対イオン結合度が 大きいことが影響している可能性がある。

最後に, SPA 蛍光消光のイオン選択性を利用して, 塩化物イオンを対イオンとする界面活性剤との混合系 について検討し，対イオンの混合ミセルへの競争結合 の知見が得られないか試みた。DPI-DTAC および HFOPI-DTAC 混合系に打ける SPA 蛍光消光挙動を検討 し，DPI または HFOPI 濃度に対して Stern-Volmer プ ロットした結果を Fig. 8 に示した。なお，DPI-DTAC 混合系に打けるDPIの仕込みモ儿分率を $\mathrm{X}_{\mathrm{I}}$, HFOPIDTAC 混合系に打ける HFOPI の仕込みモル分率を $\mathrm{X}_{\mathrm{F}}$ としている。CMC 以下では，DPI 濃度に対して SternVolmer プロットは良い直線関係を示し, DTAC モノ マー共存の影響は見られない。また, CMC 以上では, DPI-DTAC 混合系は DPI 単独系（Fig. 6）と異なる挙動

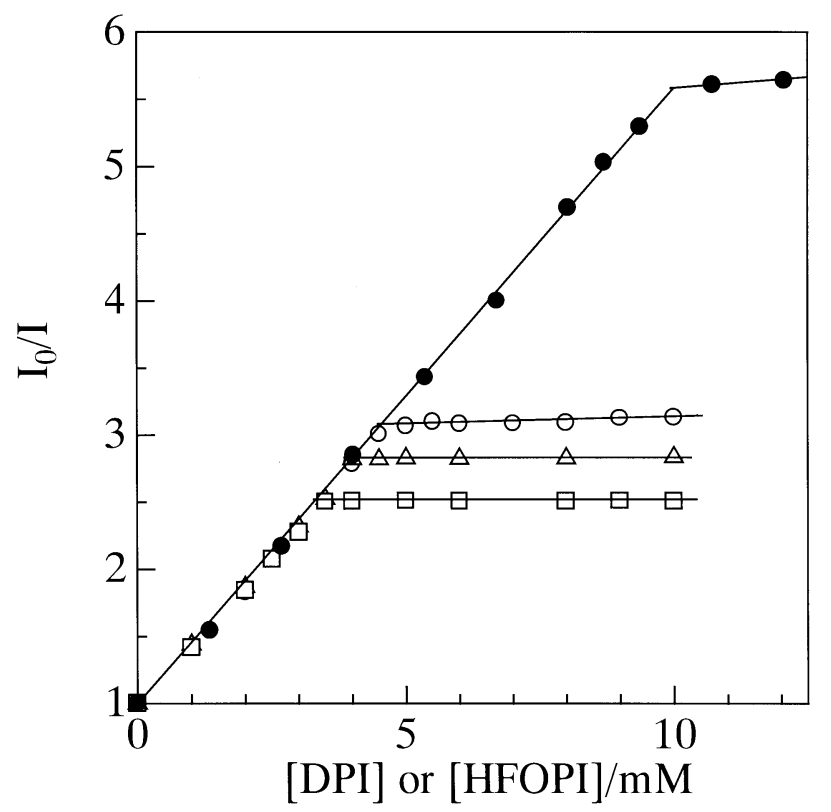

Fig. 8 Fluorescence Quenching Behavior in Mixtures by Iodide Ions with SPA Excitation at $416 \mathrm{~nm}$. $\mathrm{X}_{\mathrm{I}}$ and $\mathrm{X}_{\mathrm{F}}$ are the Mole Fractions of DPI and HFOPI in Mixtures, Respectively.
(○) $\mathrm{X}_{\mathrm{I}} 0.67,(\triangle) \mathrm{X}_{\mathrm{I}} 0.5,(\square) \mathrm{X}_{\mathrm{I}} 0.4$ DPI-DTAC,
(๑) $X_{F} 0.67$ HFOPI-DTAC.

を示すのに対し，HFOPI-DTAC 混合系は HFOPI 単独 系（Fig. 6） と似た消光挙動を示した。また, SternVolmer プロットに打ける屈曲点が DTAC のモル分率増 加とともにDPI 低濃度側にシフトした。これは，混合 ミセルを形成するためである。また, CMC 以上に打け る Stern-Volmer プロットの傾きがほぼゼロであるのは， 混合ミセルに詨するヨウ化物イオンの結合が強いこと を示している。ヨウ化物イオンが混合ミセル表面のド デシルトリメチルアンモニウム親水基と強く相互作用 することは，ヨウ化物イオンとピリジン環との電荷移 動吸収バンドの消失からも確認できた。一方, HFOPIDTAC 混合系の $\mathrm{X}_{\mathrm{F}}=0.67$ の消光挙動は HFOPI 単独系 とほぼ一致する点や, DTAI の沈殿を生じやすい点から 考えると, ミセル中で両界面活性剤が混合しにくいこ とを示している。すなわち, DPI-DTAC 混合系では， 混合ミセルを形成するため沈殿は生じにくいのに対し， HFOPI-DTAC 混合系では, フッ素系ミセルにドデシル トリメチルアンモニウムが可溶化しにくいためクラフ ト点の高いDTAI の沈殿が生じやすい。また, HFOPI の CMC や消光挙動に対して DTAC 添加による影響が 少ないことから，ドデシルトリメチルアンモニウムが 混合ミセル形成にあまり関与していないことが示唆さ れる。

\section{4 結 論}

現在までヨウ化物イオンを対イオンとするミセルの 対イオン結合度の報告例は少ないが, SPA 蛍光消光挙 動を利用すると，CMC と対イオン結合度が簡便に決定 できることが明らかとなった。また, SPA 蛍光消光の 特性からヨウ化物イオンの混合ミセルへの優先的な結 合が確認でき, 短波長側で励起すると電荷移動吸収バ ンドの存在を推察できることがわかった。また，ヨウ 化物を対イオンとする界面活性剤は沈殿を起こしやす い等，イオン選択性電極では界面活性剤の電極への吸 着でデータの再現性が問題となることがある。蛍光測 定では，そのような問題は回避でき, 比較的少量のサ ンプルでも CMC や対イオン結合度を簡便に評価でき る。

\section{Reference}

1. K. FUJIO and S. OZEKI, Counterion Binding to Ionic Surfactant Micelles, J. Jpn Oil Chem. Soc., Vol. 49, 221-229 (2000).

2. T. MAEDA and I. SATAKE, The Micellar Properties of Dodecyltrimethylammonium Chloride as Studied by Ion-Selective Electrodes and Fluorescence Probe Method, Bull Chem. Soc. Jpn, Vol. 61, 1933-1937 (1988).

3. T. INGRAM and M.N. JONES, Membrane Potential Studies on 
Surfactant Solutions, Trans Faraday Soc., Vol. 65, 297-304 (1968).

4. J.M. DEL RIO, C. POMBO, G. PRIETO, V. MOSQUERA and F. SARMIENTO, Effect of Temperature and Alkyl Chain Length on the Micellar Properties of n-Alkyltrimethylammonium Bromides in a Low pH Medium, J. Colloid Interface Sci., Vol. 172, 137-141 (1995).

5. M. JANSSON and R. RYMDEN, Counterion Binding in Aqueous Solutions of Mixed Micellar Aggregates from Self-Diffusion Measurements, J. Colloid Interface Sci., Vol. 119, 185-193 (1987).

6. P. MUKERJEE and A. RAY, Charge-Transfer Interactions and the Polarity at the Surface of Micelles of Long-Chain Pyridinium Iodides, J. Phys. Chem., Vol. 70, 2144-2149 (1966).

7. P. MUKERJEE and A. RAY, The Specificity of Counterion Adsorption to Micelles of Dodecylpyridinium Iodides and Their Critical Concentrations, J. Phys. Chem., Vol. 70, 2150-2157 (1966).

8. T. ASAKAWA, H. HISAMATSU and S. MIYAGISHI, Micellar
Pseudophase Separation Regions of 1H,1H,2H,2H-Perfluoroalkylpyridinium Chloride and Hydrocarbon Surfactants by Group Contribution Method, Langmuir, Vol. 11, 478-482 (1995).

9. J. BIWERSI, B. TULK and A.S. VERKMAN, Long-Wavelength Chloride-Sensitive Fluorescent Indicators, Anal. Biochem., Vol. 219, 139-143 (1994).

10. T. ASAKAWA, H. KITANO, A. OHTA and S. MIYAGISHI, Convenient Estimation for Counterion Dissociation of Cationic Micelles Using Chloride-Sensitive Fluorescence Probe, J. Colloid Interface Sci., Vol. 242, 284-287 (2001).

11. P. MUKERJEE and A.Y.S. YANG, Nonideality of Mixing of Micelles of Fluorocarbon and Hydrocarbon Surfactants and Evidence of Partial Miscibility from Differential Conductance Data, J. Phys. Chem., Vol. 80, 1388-1390 (1976).

12. K. SHINODA and T. NOMURA, Miscibility of Fluorocarbon and Hydrocarbon Surfactants in Micelles and Liquid Mixtures. Basic Studies of Oil Repellent and Fire Extinguishing Agents, $J$. Phys. Chem., Vol. 70, 2150-2157 (1966). 